\title{
Guide to Using Rhizomal Perennial Peanut in the Urban Landscape ${ }^{1}$
}

\author{
Robert E. Rouse, Elan M. Miavitz, and Fritz M. Roka ${ }^{2}$
}

\section{Introduction}

\section{Common Name: Perennial peanut (Fig.1)}

Scientific name: Arachis glabrata, Benth

Origin: Tropical South America

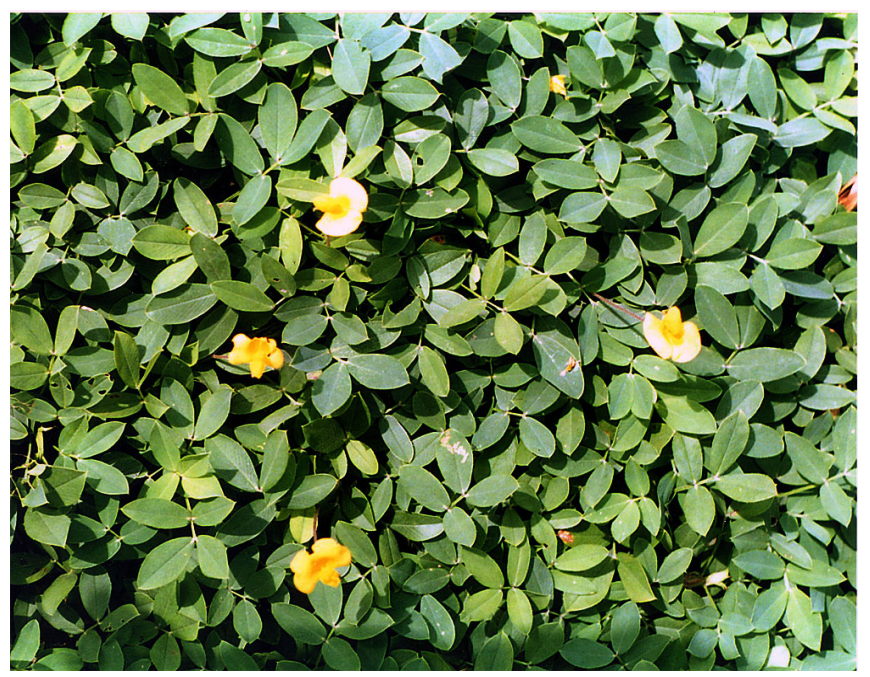

Figure 1. Perennial peanut canopy with yellow-gold flowers.
The perennial peanut evolved in tropical conditions and is adapted to subtropical and warm temperate climates. In the northern hemisphere, this would include locations below $32^{\circ}$ north latitude (Florida-Georgia state line) having a long, warm growing season.

Perennial peanut was first introduced from Brazil in 1936 and since that time no insect, disease, or nematode pests have been identified that cause economic loss. Since its introduction, it has not spread into natural areas or become a nuisance plant in unimproved properties. Rhizomal perennial peanut does not reproduce by seed; therefore, it can't be carried by birds or wildlife or transported in plant material to unintended areas.

Perennial peanut has recently shown promise as an ornamental groundcover due to its high resistance to drought, nematodes, and pathogens and its minimal fertilizer needs. This translates into savings in water, energy, dollars, and reduced impacts to the environment. It is not only beneficial to the environment since it requires no supplemental nitrogen or phosphorus fertilization or pest control,

1. This document is HS960, one of a series of the Horticultural Sciences Department, Florida Cooperative Extension Service, Institute of Food and Agricultural Sciences, University of Florida. Publication date: March 2004. Visit the EDIS Web site at http://edis.ifas.ufl.edu.

2. Robert E. Rouse, associate professor, Department of Horticultural Science, Southwest Florida Research and Education Center, Immokalee, FL; Elan M Miavitz, horticulture agent, Collier County Extension Office, Naples, FL; Fritz M. Roka, assistant professor, Department of Food and Resource Economics, Southwest Florida Research and Education Center, Immokalee, FL; Florida Cooperative Extension Service, UF/IFAS, University of Florida, Gainesville, FL.

The Institute of Food and Agricultural Sciences (IFAS) is an Equal Employment Opportunity - Affirmative Action Employer authorized to provide research, educational information and other services only to individuals and institutions that function without regard to race, creed, color, religion, age, disability, sex, sexual orientation, marital status, national origin, political opinions or affiliations. For information on obtaining other extension publications, contact your county Cooperative Extension Service office. Florida Cooperative Extension Service / Institute of Food and Agricultural Sciences / University of Florida / Larry R. Arrington, Interim Dean 
but it also is aesthetically pleasing, can be walked on, and has edible, peanut flavored flowers.

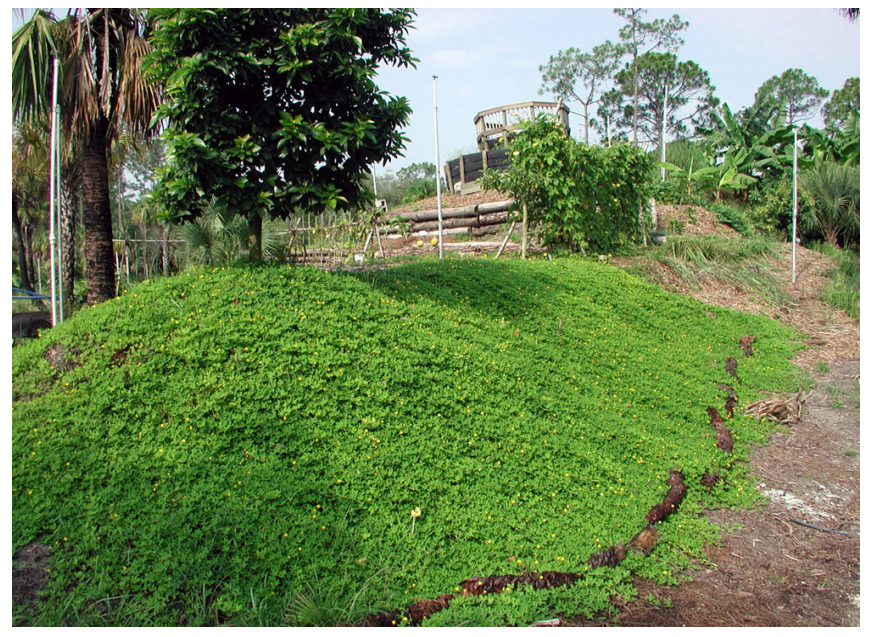

Figure 2. Perennial peanut used on a landscape berm.

Due to rapid urbanization, water has become a precious commodity in Florida. Water management districts are encouraging the implementation of year-round water restrictions and the use of drought tolerant plants, of which perennial peanut is a good candidate. Perennial peanut has potential landscape uses as a groundcover in home landscapes (Fig. 2, Fig. 5), road medians (Fig. 3, Fig. 4), driveways and parking lot islands (Fig. 6), golf courses, along berms, septic tank mounds, and canal banks. Perennial peanut can also be used as a buffer to waterways prone to runoff high in $\mathrm{N}$ (Nitrogen) and $\mathrm{P}$ (Phosphorus).

\section{Perennial Peanut in the Urban Landscape}

\section{Success Stories}

In Florida, the city of Jacksonville uses perennial peanut in medians; Highway 19 south of Chiefland has a 30-year-old stand of 'Arblick' in the median; and Tampa Bay Skyway also has a highway planting of perennial peanut growing in limerock.

In Guanacaste Province, Costa Rica, medians, lawns, hotel entryways, and roadsides are planted with perennial peanut. Although this region is in a dry forest for 10 months of the year, these perennial peanut areas remain green without having to be mowed, fertilized, or irrigated.

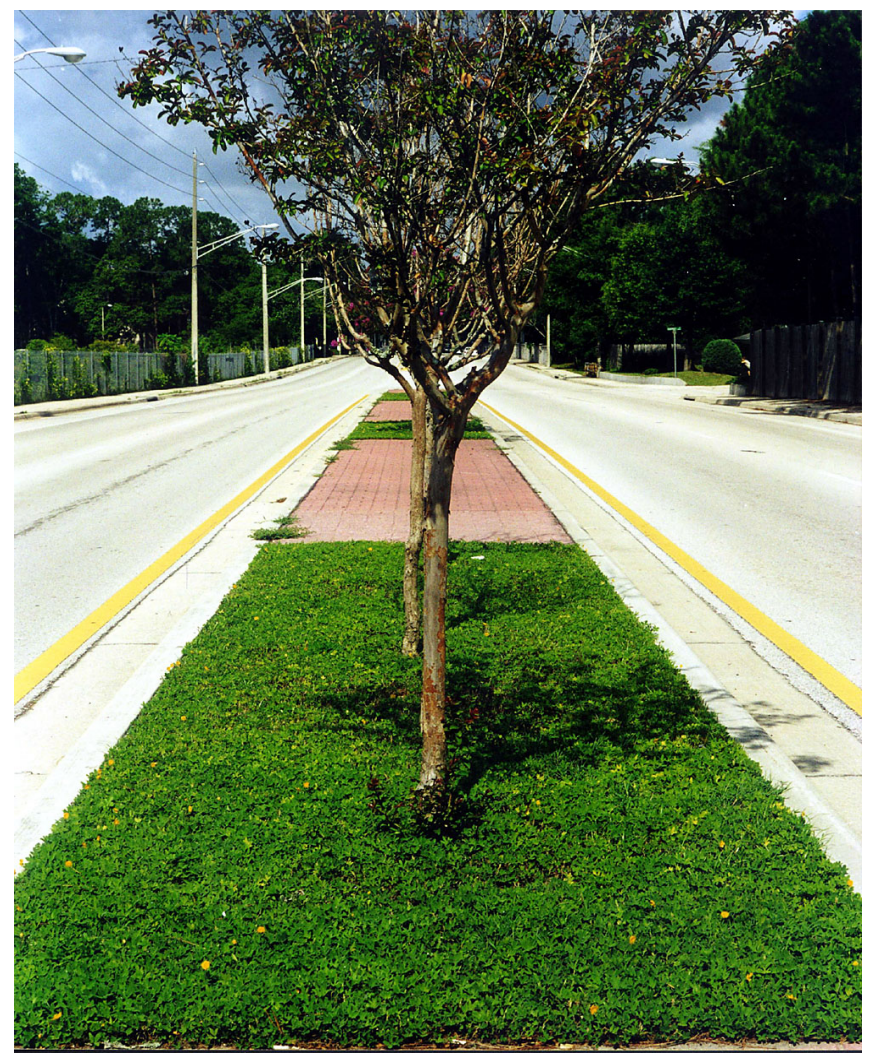

Figure 3. Perennial peanut groundcover in a road median.

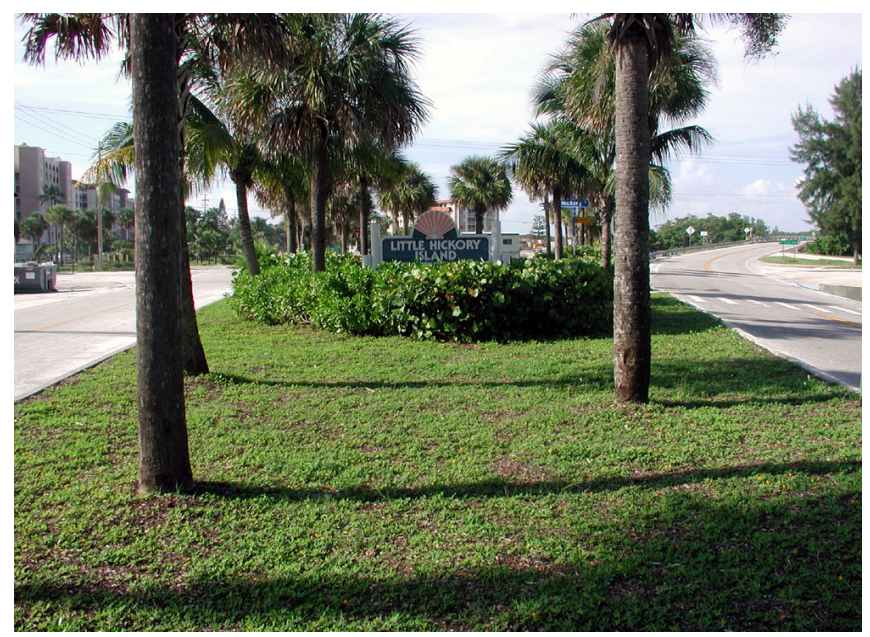

Figure 4. Perennial peanut four weeks after planting in a median near the ocean.

\section{New Users}

Perennial peanut is used as a forage legume for grazing, as a high-value hay crop, and has been planted as a cover crop in citrus. Several cultivars are available for use in home landscapes.

Rhizome perennial peanut has several potential advantages in the managed landscape. As its name implies, perennial peanut is long-lived and doesn't require replanting once established. 


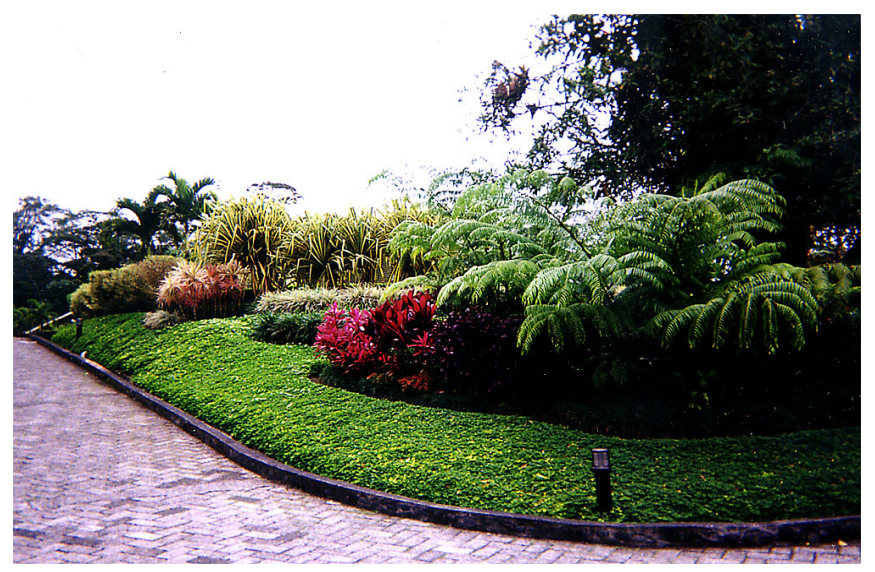

Figure 5. Perennial peanut in a formal landscape.

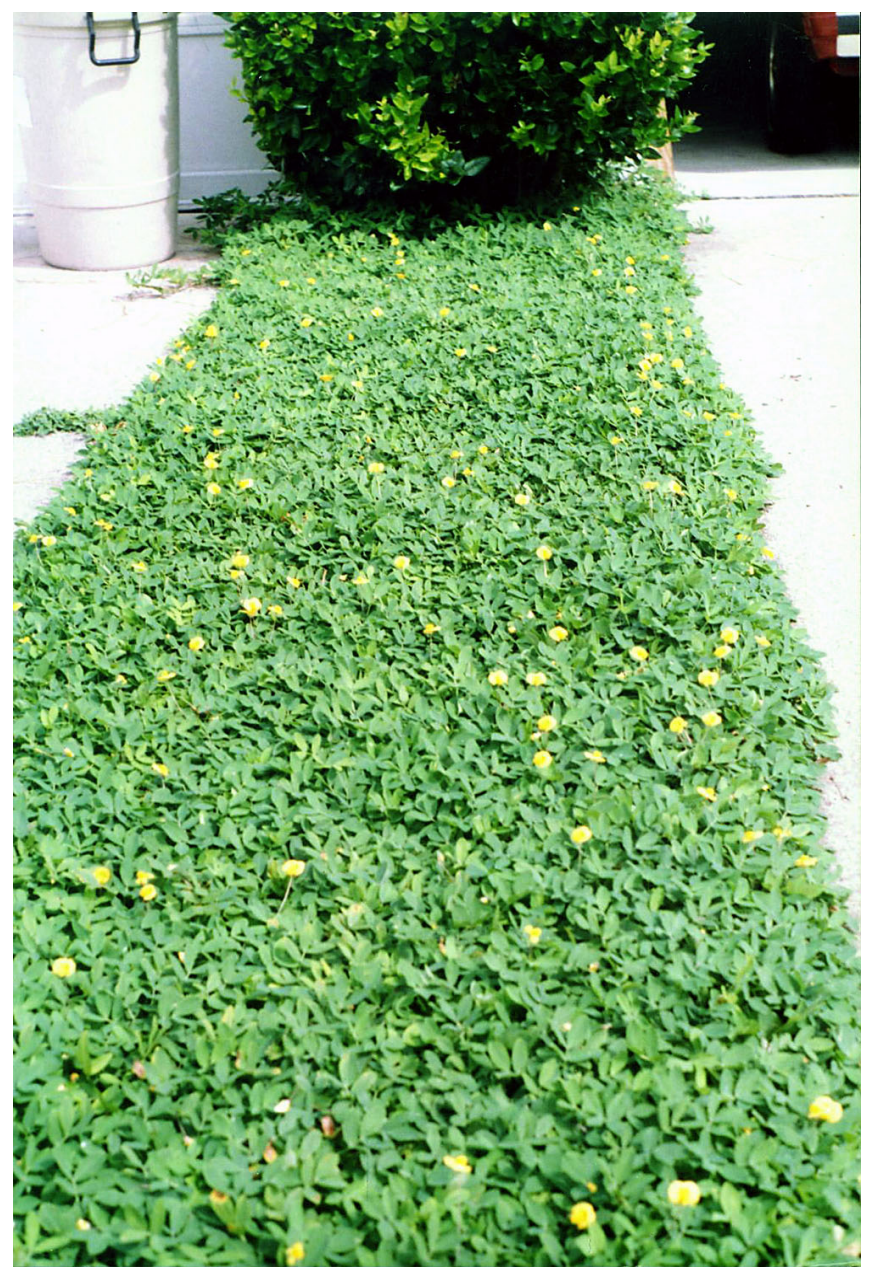

Figure 6. Perennial peanut groundcover used with a divided driveway.

Perennial peanut is best suited to south Florida conditions where winter frosts are infrequent.

Perennial peanut has been successful in north and central Florida conditions where annual frosts occur, damaging above-ground foliage. Peanut is adapted to the droughty, infertile sands of Florida. The peanut legume, in association with Rhizobium, fixes atmospheric N. This means that it requires no applied external nitrogen source. Phosphorus applications may be unnecessary in Florida sands rich in P. The peanut legume is highly resistant to plant and soil pests.

Perennial peanut may suppress weed growth, reduce nutrient leaching, and add nitrogen and organic matter to the soil. On the other hand, all cover crops have the potential to compete with trees for water and nitrogen.

\section{Site Considerations}

\section{Climatic Information}

Perennial peanut grows best in full sun (Fig. 7) and when days are long, hot, and humid. Perennial peanut will persist in partial shade (Fig. 8) with little or no mowing, but canopy thickness and groundcover will be reduced. Irrigation has proven beneficial during establishment and dry seasons.

\section{Soil Adaptability and Preparation}

Perennial peanut is adapted to a variety of well-drained soil types and does well in the sands of Florida. Perennial peanut has had mixed success in high $\mathrm{pH}$ soils and reclaimed phosphatic, highly colloidal clay soil in Florida. High alkaline soils may tend to cause yellow or chlorotic growth.

Soil tests should be made prior to planting to determine needs for phosphate $(\mathrm{P})$, potassium $(\mathrm{K})$, sulfur (S), and other nutrients . When Mehlich-I soil test level is below $30 \mathrm{ppm} P$, apply 0.7 pounds $\mathrm{P} 2 \mathrm{O} 5 / 1000 \mathrm{ft}^{2}$. K should be applied at 1.4 pounds $\mathrm{K} 2 \mathrm{O} / 1000 \mathrm{ft}^{2}$ when Mehlich-I soil test level is below 20 ppm K. Apply 0.35 pounds magnesium $(\mathrm{Mg})$ as magnesium sulfate per $1000 \mathrm{ft}^{2}$ if Mehlich-I soil test is below $30 \mathrm{ppm} \mathrm{Mg}$. Perennial peanut performs well in a wide range of soil $\mathrm{pH}$. Modify soil $\mathrm{pH}$ only if measured $\mathrm{pH}$ is outside the range of 5.0 to 7.5. Research has shown that perennial peanut responds positively to applied elemental sulfur at 0.5 to 0.7 pounds per $/ 1000 \mathrm{ft}^{2}$. Since perennial peanut is a legume with nitrogen-fixing capability, it does not require the application of nitrogen fertilizer. 


\section{Salt Tolerance for Coastal Areas}

Perennial peanut can tolerate salt spray, salt drift, and short term saltwater flooding. There are several successful coastal plantings of perennial peanut in St. Augustine, Key West, Marco Island, and Bonita Springs. These plantings are in good condition and have not been affected by salt.

\section{Weed Control}

Weed problems can be reduced if the site is properly prepared before planting. All existing vegetation should be killed or removed. If perennial broadleaf weeds or grasses are present before planting, apply a nonselective herbicide, such as Roundup®. Soils with known disease or nematode incidence do not negatively affect perennial peanut

\section{Planting Considerations}

\section{Cultivars}

'Ecoturf' and 'Arblick' are available cultivars for landscape use. Both 'Ecoturf' and 'Arblick' were selected for landscape application due to their lower growth habit and profuse flowering. Planting material for 'Ecoturf' and 'Arblick' are available in limited supply. 'Florigraze' was released in 1978 for use in pastures and has been used recently in citrus groves and along roadways. 'Florigraze' also appears to be suitable for landscape use.

\section{Source}

Perennial peanut is propagated vegetatively using rhizomes (modified underground stems) that concentrate in a 1.5- to 3-inch-thick mat, just below the soil surface. It can be purchased as cut sod, rolled mats of sod, or in nursery containers.

\section{Pre-plant Care of Rhizome}

Rhizome sod should be planted as soon after digging as possible. Rhizome sod cannot be stored for more than five days without deterioration, even under the best conditions. Rhizome sod should be stored in a shady, cool location and covered with black plastic or a tarp to prevent drying. Rhizome sod that is being transported should be covered with a tarp to prevent drying. Perennial peanut in containers can be held for an extended period with proper care.

\section{Planting Time}

Perennial peanut has been traditionally planted from January through March, when it is not actively growing. Unfortunately, this is the time of year when there is limited rainfall throughout Florida. Perennial peanut can be successfully established anytime if irrigation is available, or during the summer rainy season (June - August) in Florida. Normal spring rains are important for proper root and top development. When soil moisture is low, a percentage of shoots will die due to lack of supporting roots. Irrigation during this initial development period provides insurance against plant loss or complete planting failure. Once a root system has developed, irrigation is not required. However, to maintain a strong vegetative cover, irrigation will be required during periods of low or no rain. Water, fertilizer, and weed control are all important inputs that can maximize plant density during the first growing season.

\section{Planting Methods and Density}

Several systems can be used for planting perennial peanut in a landscape setting.

Plants can be established from solid set sod, sod strips, sod plugs, or from plants grown in nursery containers. With all the above-mentioned methods except solid sod, the planting density can be adjusted to allow the perennial peanut to fill-in between planted material. Strip planting (Fig. 7) can be done using sod strips as they are delivered or cut into smaller strips, but strips should not be narrower than 8 to 10 inches. Rows can be 12 but not more than 18 inches apart.

Sod plugs can be cut from the delivered sod pieces and cut into smaller squares and planted in checkerboard layout. Sod plugs should be planted on centers no more than 12 to 18 inches apart. Plants in one-gallon nursery containers can be planted the same as sod plugs.

One additional planting method, although not recommended for urban landscapes, involves placing rhizome pieces into furrows and covering with loose soil. If this practice is tried, the rhizomes shouldn't be placed more than 1.5 to 2 inches deep. The 


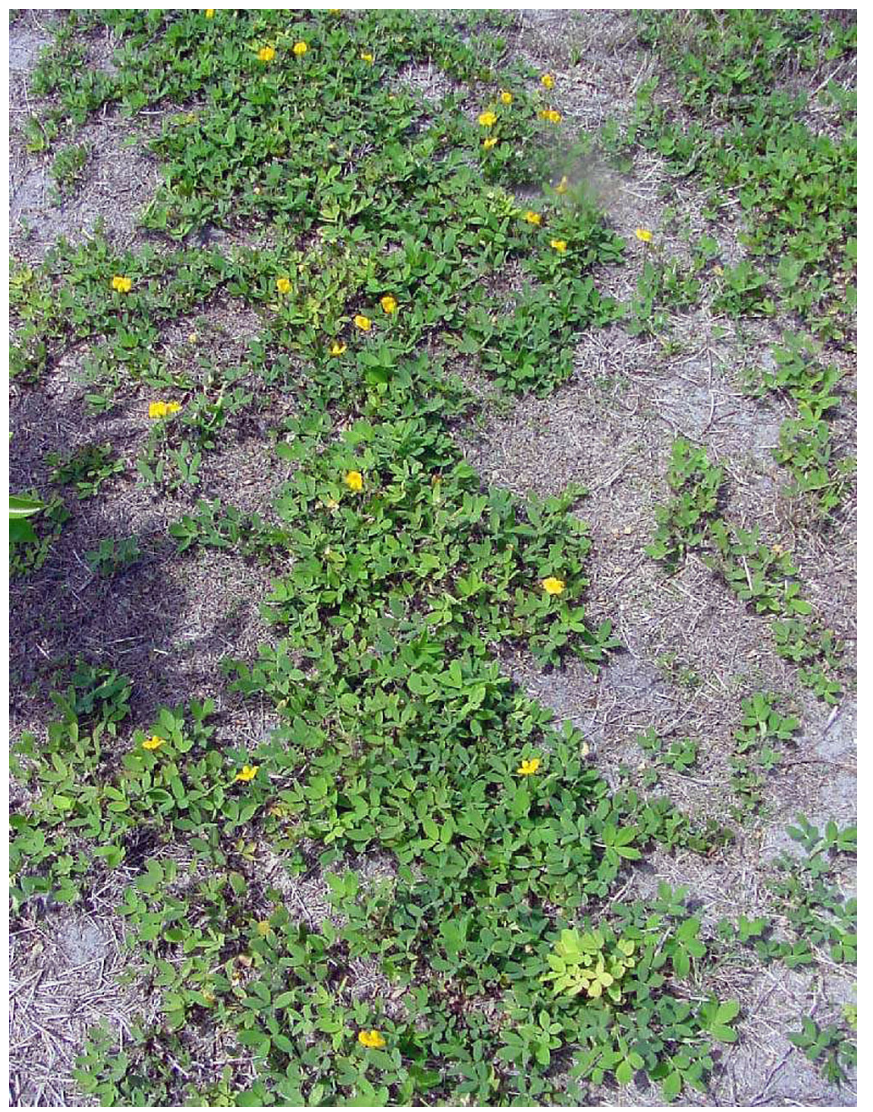

Figure 7. Perennial peanut during establishment from strip planting.

distance between planted rows of rhizomes should be kept to no more than 12 to 18 inches. Coverage time (fill-in) usually will increase as distance between rows decreases. Planting should be followed by a packing-roller that leaves the ground leveled, preserves soil moisture, and achieves good rhizome-soil contact. Irrigation should follow planting and roller packing.

\section{Maintenance Considerations}

\section{Invasiveness in Planned Landscapes}

The perennial peanut spreads by underground rhizomes in the urban landscape. Edging practices can be used to keep the plant confined. Perennial peanut has not become a nuisance weed in the planned landscape.

\section{Irrigation}

Once established, rhizomal perennial peanut may require irrigation during dry periods to maintain a thick canopy. Soil-plant moisture status should be carefully monitored during dry months.

\section{Mowing}

Mowing is not required, but appearance will be enhanced. Mowing stimulates new vegetative shoots, making a thick canopy and encouraging flowering. Mowing at 3 to 4 inches every 3 to 4 weeks is usually adequate.

\section{Nutrient Management and Fertilizer}

Like all legumes, perennial peanut obtains its nitrogen from Rhizobium species bacteria associated with the plant's root system. Because perennial peanut is propagated by rhizomes that carry the bacteria, it isn't necessary to inoculate the rhizomes at planting. The perennial peanut needs no applied N, but requires $\mathrm{P}, \mathrm{K}$, and $\mathrm{Mg}$. Since Florida soils usually contain adequate $\mathrm{P}$, these nutrients can be supplied with the addition of a common fertilizer of potassium-magnesium sulfate (analysis $0-0-22-22 \mathrm{~S}-11 \mathrm{Mg}$ ) found at most garden stores.

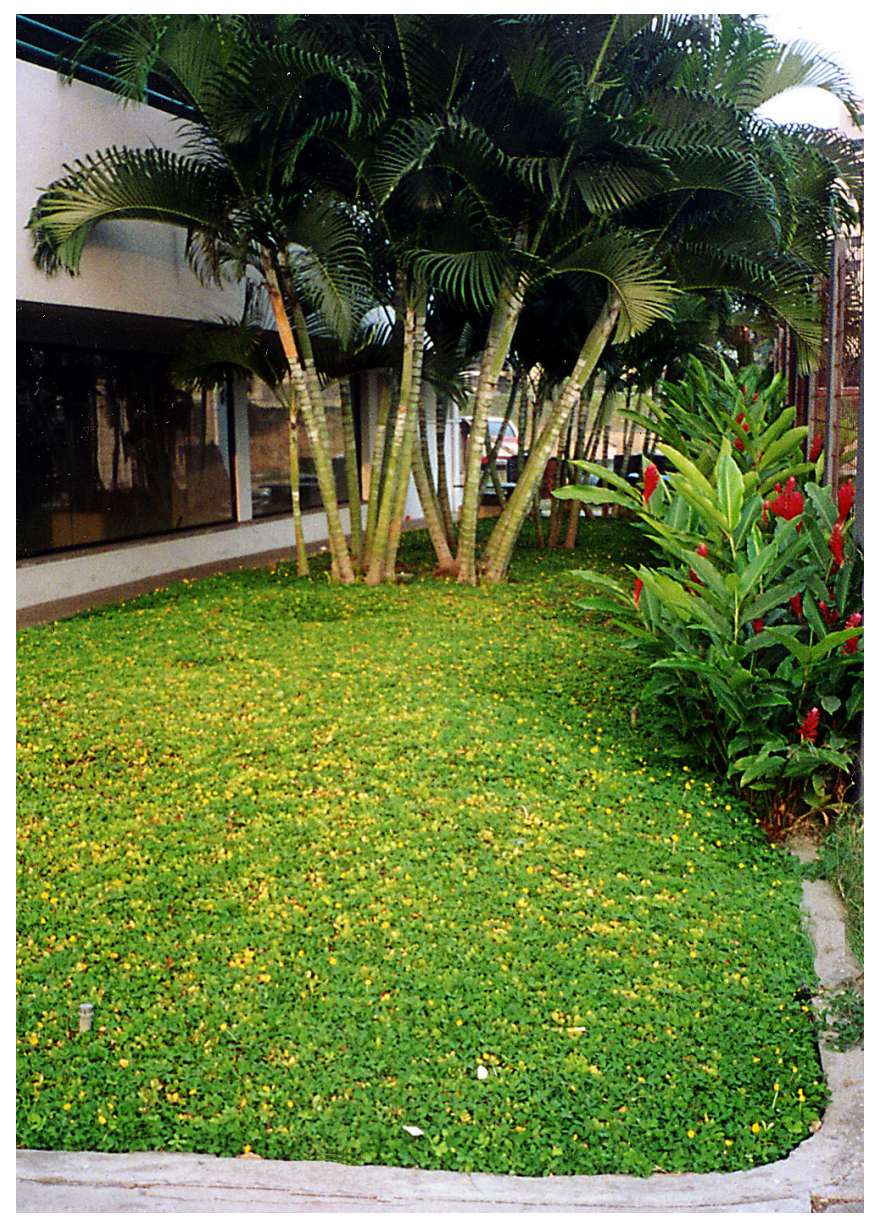

Figure 8. Perennial peanut used in a mall area with partial sun and shade. 


\section{Weed Control}

Weed control is the major management problem during establishment. Eliminating competitive weeds ensures greater survival during the dry months before the summer rainfall and allows the plants to grow and spread more rapidly. Keeping the perennial peanut canopy clear for maximum sunlight penetration is critical to proper development and speeds establishment. Common bermuda grass, torpedo grass, and nutsedge are the most persistent weed problems. Mowing should be done whenever weeds are shading the perennial peanut. Mow weeds at a level just above the foliage of the perennial peanut. Mowing has been found to be the least expensive weed control method.

Other methods of weed control do not appear to reduce establishment time. For grassy weeds such as crabgrass, bermudagrass, and bahiagrass, the herbicides Fusilade $\AA$, Poast ${ }^{\circledR}$, Select ${ }^{\circledR}$, and Prism $\AA$ are cleared for use during establishment. Basagran ${ }^{\circledR}$ is effective for control of yellow nutsedge as well as a few other select broadleaved weeds. It is approved for use on perennial peanut during establishment.

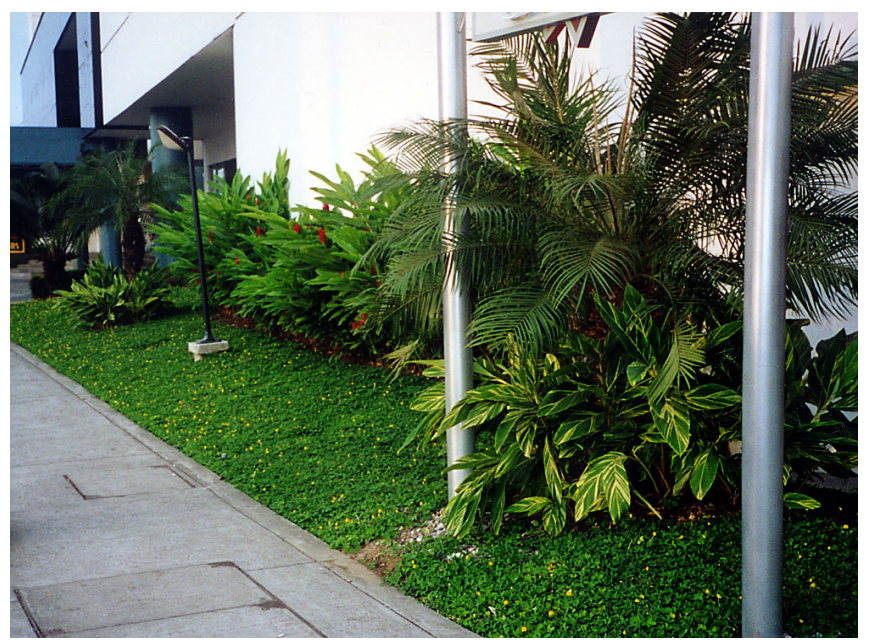

Figure 9. Perennial peanut along a street and commercial building.

Herbicide recommendations in this publication are contingent upon their continued registration by the Environmental Protection Agency. If a registration is canceled, the herbicide can no longer be recommended. The use of product trade names does not constitute a guarantee or warranty of the products named and does not signify approval to the exclusion of similar products.

\section{Economic Considerations}

Enterprise budgets were developed to compare the costs of growing St. Augustinegrass versus perennial peanut. Establishment costs were developed separately from annual maintenance costs. Costs of applying fertilizer, herbicides, and pest control products were based on typical rates charged by commercial lawn-care companies.

During the summer of 2002, sixteen commercial lawn-care companies participated in a telephone survey to solicit cost information for lawn-care services. These companies operated in the Naples/Ft Myers region of southwest Florida. Services included sod installation, fertilizer applications and chemical treatments, and grass mowing. All companies handled St. Augustinegrass lawns. Few companies had any experience with perennial peanut groundcover. Sod installation was priced on a square foot basis and included both the grass and labor to lay the sod.

As a rule, lawn-care companies charge a flat fee per lawn service. Mowing services averaged $\$ 35$ per residential lot. Fertilizer and chemical application treatment ranged from $\$ 4$ to $\$ 7$ per $1,000 \mathrm{ft}^{2}$ for each treatment. Fees include not only material costs but also labor and equipment costs. Given that an average residential lot in southwest Florida is only 5,000 $\mathrm{ft}^{2}$, the cost of fertilizer or chemical products is small relative to the labor and equipment cost to apply a specific treatment. Consequently, specific fertilization, chemical products, and application rates are not listed in this publication. For specific management recommendations and chemical rates, consult the Florida Lawn Handbook for St. Augustinegrass and EDIS document SS-AGR-19 for perennial peanut.

Establishment costs of both perennial peanut and St. Augustinegrass are outlined in Table 1. In both cases, it was assumed that sod would be used to establish equivalent areas. Perennial peanut sod is more expensive to establish than St. Augustinegrass sod. Including the labor to install the sod, perennial peanut would cost an estimated $\$ 1,250$ per $1,000 \mathrm{ft}^{2}$, more than four times as expensive as St.

Augustinegrass sod. For either St. Augustinegrass or perennial peanut groundcover, a starter fertilizer 
application is necessary. Sufficient water is critical for either St. Augustinegrass or perennial peanut during the first 30 days after establishment. St. Augustinegrass sod, however, requires more than 60 percent greater water volume during establishment than does perennial peanut. If planting of St. Augustinegrass or perennial peanut occurs during the summer rainy season, minimal supplemental irrigation would be required. For the purpose of this paper and cost comparison, it was assumed that the entire volume of water would be supplied by supplemental irrigation and priced at residential rates.

Table 1 indicates that more than $\$ 900$ dollars (per 1,000 $\mathrm{ft}^{2}$ ) of additional cash would be needed to establish perennial peanut versus St. Augustinegrass. On an annual basis, establishment costs depends on the expected life. As shown in Table 1, annual establishment costs decrease as expected life increases. Several lawn-care companies interviewed during 2002 indicated that fungal diseases and pest pressures force many St. Augustinegrass lawns to be replaced every ten years. Evidence from perennial peanut plots suggests a high degree of tolerance to a variety of pests. Therefore, one could expect a perennial peanut groundcover to last significantly longer than St. Augustinegrass. However, for the purposes of this document, it was assumed that St. Augustinegrass lawns received an adequate level of management, thereby sustaining a healthy stand indefinitely.

The economic benefits from perennial peanut emerge from a comparison of annual maintenance costs between a perennial peanut groundcover and St. Augustinegrass sod. Table 2 itemizes estimated annual maintenance costs by four categories fertilization, pesticides (chemical treatments), irrigation water, and mowing. As mentioned previously, the costs of lawn mowing and applications of fertilizer and lawn chemicals are based on rates charged by commercial lawn care companies. These rates fully account for material, labor, equipment, and related overhead expenses.

The annual maintenance cost of a well-established perennial peanut groundcover is estimated to be $\$ 64$ per $1,000 \mathrm{ft}^{2}$. Annual maintenance costs of a St. Augustinegrass lawn surpass $\$ 350$ per $1,000 \mathrm{ft}^{2}$, more than five times higher than perennial peanut. Most of the cost savings with perennial peanut are realized in lower mowing costs. The low-growing perennial peanut requires mowing only once every four weeks during the rainy season, as mowing is necessary mainly for weed control.

The perennial peanut's drought tolerance means that supplemental irrigation is not necessary during the dry season. Conversely, nearly 20,000 gallons of irrigation water is required to maintain $1,000 \mathrm{ft}^{2}$ of St. Augustinegrass through the dry season in south Florida at an estimated cost of $\$ 56$ per 1,000 $\mathrm{ft}^{2}$.

Given the estimated savings in annual maintenance costs, a perennial peanut groundcover would offset the higher establishment costs within 3.2 years. For every year afterwards, an annual cost savings of nearly $\$ 300$ per $1,000 \mathrm{ft}^{2}$ of perennial peanut groundcover would be realized.

\section{References}

Beltranena, R.J. Breman and G.M. Prime. 1981. Yield and quality of Florigraze rhizoma peanut (Arachis glabrata Benth.) as affected by cutting height and frequency. Soil Crop Sci. Soc. Fla. Proc. 40:153-156.

French, E.C. and G.M. Prime. 2002. Perennial peanut establishment guide. EDIS document SS-AGR-35. Agronomy Department, Florida Cooperative Extension Service, IFAS, University of Florida.

French, E.C., G.M. Prime, and A.R. Blount. 2001. Perennial peanut: An alternative forage of growing importance. EDIS document SS-AGR-39. Agronomy Department, Florida Cooperative Extension Service, IFAS, University of Florida.

French, E.C., G.M. Prime, W.R. Ocumpaugh, and R.W, Rice. 1993. Regional experience with forage Arachis in the United States. In: P.C. Kerridge and B. Hardy (eds.) Biology and Agronomy of Forage Arachis. CIAT, Cali, Columbia. Chapter 15 pp. 16784. 
French, E.C., J.A. Stricker, G.M. Prine, R.S.

Zazueta and A.E. Dudeck. 2002. Establishment and

Management of Ornamental Perennial Peanuts. EDIS

document SS-AGR-19. Agronomy Department,

Florida Cooperative Extension Service, IFAS,

University of Florida.

McCarty, L.B. and J.L. Cisar. "Yearly Calendar for St. Augustinegrass Care and Culture." In Florida Lawn Handbook - An Environmental Approach to Care and Maintenance of Your Lawn, 2nd edition. K.C. Ruppert and R.J. Black, editors, Cooperative Extension Service, IFAS, University of Florida. University Press of Florida, Gainesville, FL, 1998, p 49-53.

Rouse, R.E., R.M. Muchovej, and J.J. Mullahey. Guide to using perennial peanut as a cover crop in citrus. 2001. EDIS document Fact Sheet HS-805. Horticultural Sciences Department, Florida Cooperative Extension Service, IFAS, University of Florida.

Rouse, R.E. and J.J. Mullahey. 1997. Perennial peanut ground cover in citrus orchard row middles and discussion of potential environmental benefits. Proceedings of the Florida State Horticultural Society. 110:79-82. 


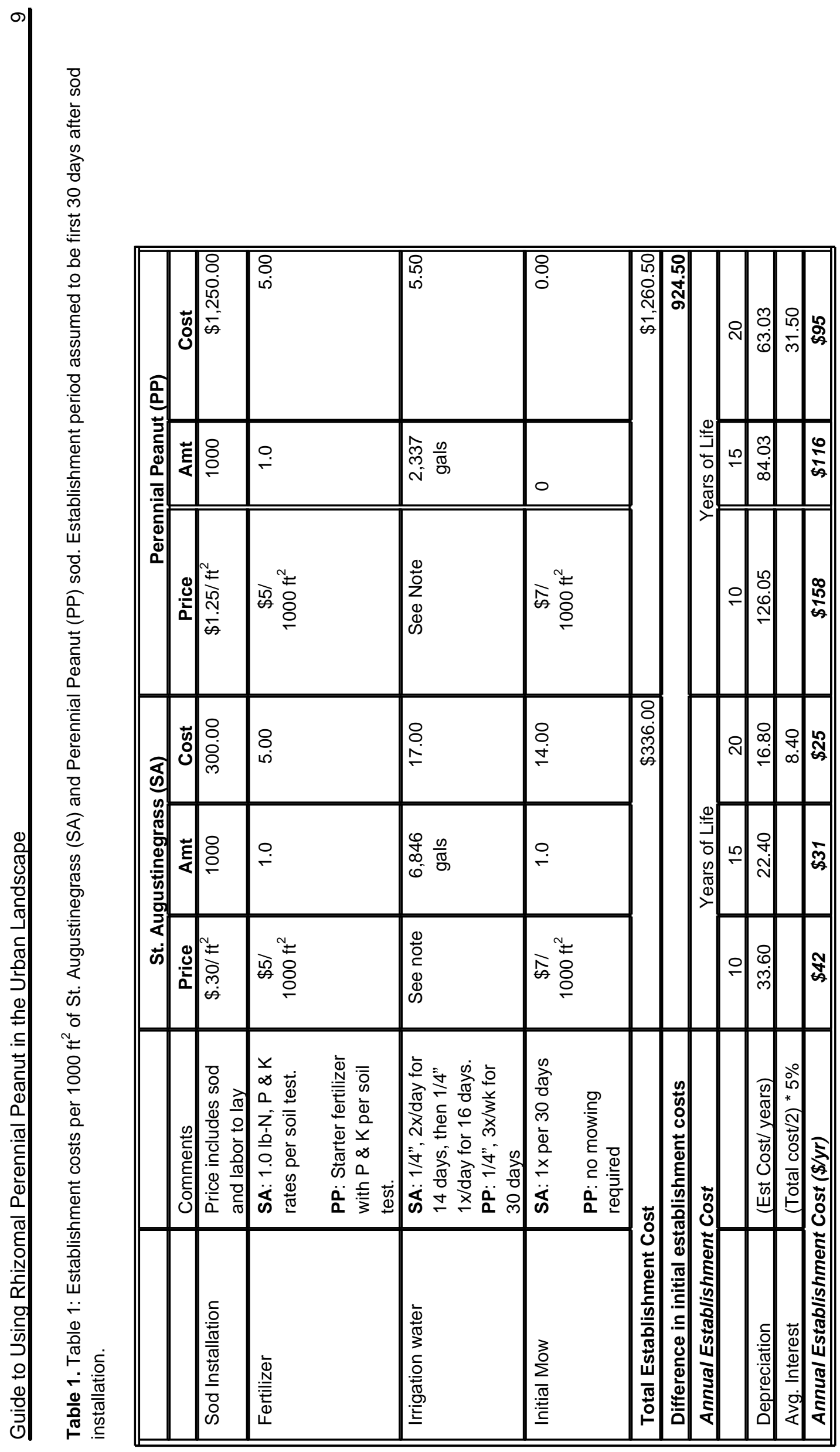



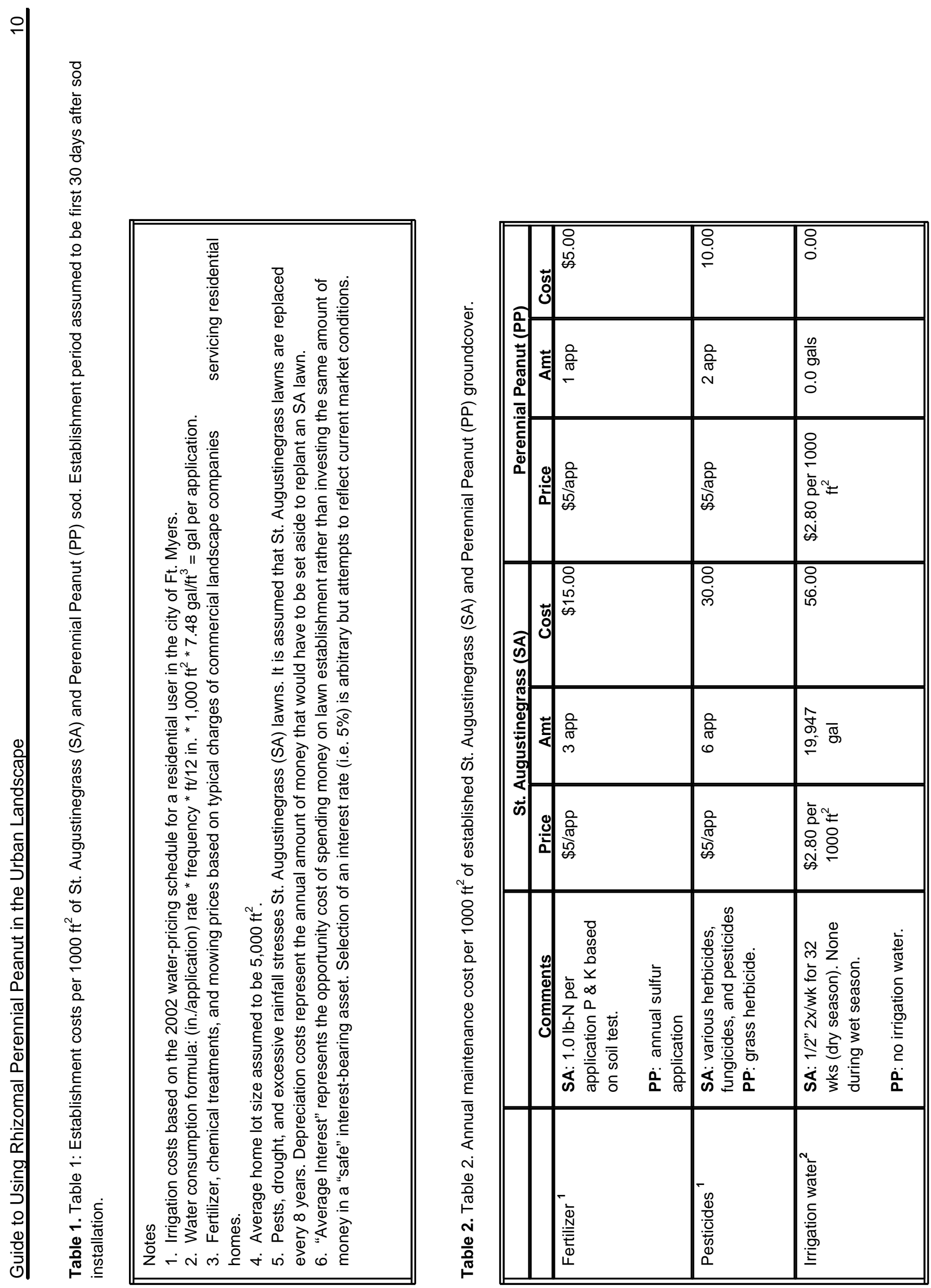


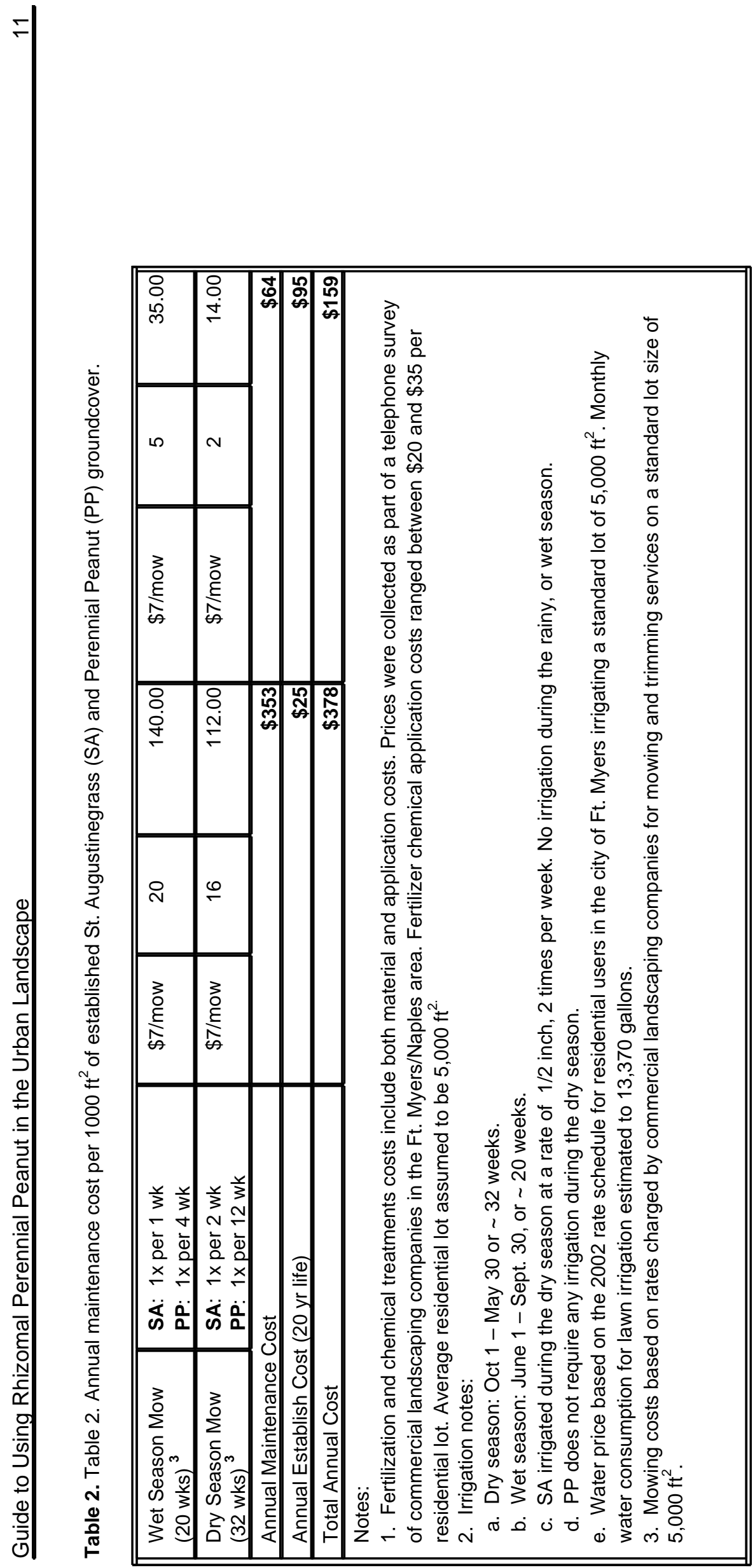

